\title{
Brachytherapy in accelerated partial breast irradiation (APBI) - review of treatment methods
}

\author{
Janusz Skowronek, MD, PhD, Ass. Prof., Magdalena Wawrzyniak-Hojczyk, MD, Kinga Ambrochowicz, MD \\ Brachytherapy Department, Greater Poland Cancer Center, Poznań, Poland
}

\begin{abstract}
Breast conserving surgery (BCS) with following radiotherapy (EBRT) of the conserved breast became widely accepted in the last decades as the treatment of early invasive breast cancer. In an early stage of breast cancer, research has shown that the area requiring radiation treatment to prevent cancer from local recurrence is the breast tissue that surrounds the area where the initial cancer was removed. Accelerated partial breast irradiation (APBI) is an approach that treats only the lumpectomy bed with 1-2 cm margin, rather than the whole breast and as a result allows accelerated delivery of the radiation dose in four to five days. Published results of APBI are very promising. It is evident that APBI will play a role in the management of a selected group of early breast cancer. We discuss current status, indications, technical aspects and recently published results of APBI using different brachytherapy techniques.
\end{abstract}

Key words: APBI, balloon, brachytherapy, breast cancer, interstitial.

\section{Purpose}

Breast cancer is the most frequently detected cancer in women in developed countries and its incidence ranges from $25 \%$ to $30 \%$ of all cancers in women. Average age of breast cancer patients range between 45 and 65, however, in recent years is noticeable that the average age of incidence tend to lower [1]. With the prevalence of screening and increasing awareness of the disease, more and more women may be treated with breast-conserving surgery (BCS) with a complementary external beam radiation therapy (EBRT) and tumor's bed dose increasing ('boost'). Results of conservative treatment supplemented by radiation therapy are as good as the results obtained after mastectomy [2-6]. Further advances in radiotherapy techniques and knowledge of the biology of breast cancer, in addition to the standard methods of combination therapy (WBRT and 'boost'), increases the application of APBI as a radical treatment in particular cases [7-11]. This method of radiation therapy is used in a selected group of patients in the early stages of the disease [3,12-17]. The main reason for APBI introduction was the assumption that it leads to obtain an equivalent local control rates with less toxicity of treatment compared with whole breast irradiation technique (EBRT) after BCS in the selected group of patients. The results of studies comparing the effectiveness of BCS + WBRT and APBI have shown that a very large percentage of local recurrence (more than $80-90 \%$ ) occurs in the immediate vicinity of the original location of the tumor.
This was the primary cause for the use of brachytherapy alone after breast-conserving therapy in a strictly selected group of patients. The advantage of this method is also shorter time of treatment from 5-7 weeks (WBRT + boost), to 4-5 days of APBI. It is supposed to be capable of reducing the rate of complications: radiation-induced reactions, telangiectasia and fibrosis. Due to increasing use of APBI methods we present the most recent reports on this subject. We describe the treatment techniques, principles of patient selection for this method, the results of treatment and current recommendations of GEC-ESTRO (Groupe Européen de Curietherapie - European Society for Therapeutic Radiology and Oncology), ABS (American Brachytherapy Society) and ASTRO (American Society for Therapeutic Radiology), three major world societies of radiation oncologists.

\section{Rationale for use of APBI}

The results of studies examining the efficacy of BCS followed by whole breast radiotherapy (WBRT) showed that a very large percentage of local recurrence arises in the immediate vicinity of the original location of the tumor (Fig. 1). At least five prospective randomized studies examining the percentage of local recurrence after radiotherapy the whole breast were published and it was found that $69 \%$ to $90 \%$ recurrences occur in immediate vicinity of the primary tumor (Table 1). In other studies, the percentage of recurrences in other quadrants than in being treated or contralateral 
breast was $0.9 \%$ to $3.5 \%$ in prospective studies and $2 \%$ to $5 \%$ in retrospective studies (Table 2). This was the basic cause for the use of brachytherapy alone after BCS treatment in a strictly selected group of patients $[5,10,15,26-28]$. Another advantage of this method pointed out by many authors is also shortening the treatment duration from 5-7 weeks (conventional EBRT) to 4-5 days, what, particularly for working women, living far away from the cancer center and older patients is important. Offeresen et al. [29] in the summary pointed out that in the U.S. socio-economic factors affect the type of surgery - poorer women (eg, paying a lower insurance premium) and/or living far from the radiotherapy center choose mastectomy, even after qualifying for the BCS. In some areas, up to $25 \%$ of older women after BCS are not irradiated from these reasons. After examination of 175000 patients with early breast cancer (SEER database) it was found that in 1992-2003 the percentage of BCS increased from $41 \%$ to $60 \%$, while the proportion of patients irradiated after BCS decreased from $79 \%$ to $71 \%$. Undoubtedly it affects the increased risk of local recurrences after BCS. Similar conclusions were reached by Njeh et al. [30] - in this article, they exchanged the factors affecting to decide RT: convenience, accessibility, cost, distance from the center of RT, lack of transportation, lack of social support, movement difficulties of patients doctor bias, age of the patient and fear of radiation. Also in Japan, only about $70 \%$ of patients are treated with radiotherapy after BCS, for similar reasons as in the U.S.

\section{Indications for APBI}

Recommendations of the American Brachytherapy Society (ABS) and the American Society of Breast Surgeons (ASBS) on the qualifications for APBI are shown in Table 3 [31], while the GEC-ESTRO (Groupe Européen de Curiethérapie European Society for Therapeutic Radiology and Oncology) recommendations are posted in Table 4 [32].

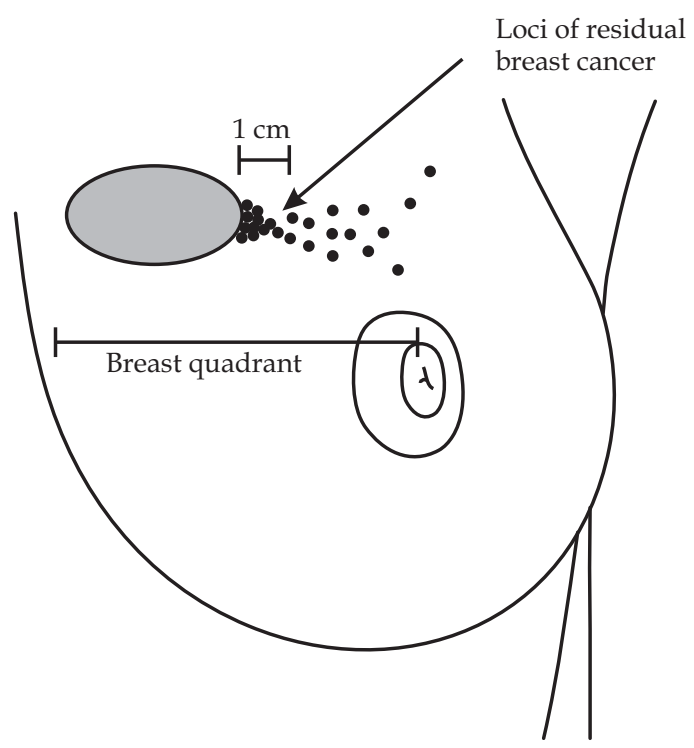

Fig. 1. Schematic location of the satellite foci of cancer in the immediate vicinity of the primary tumor

\section{Contraindications for APBI}

It lists: clinical stage III or IV, no evaluation of surgical margins, presence of extensive intraductal component (EIC), Paget's disease, infiltration or other changes in skin, present contralateral breast cancer (or in the past), previous others cancers (within 5 years from eligibility for the study) with the exception of skin cancer and 0 or I stage FIGO cervical cancer (previous), pregnancy or lactation period, connective tissue disorders, collagen diseases, genetic or metabolic proceeding with hypersensitivity to radiation such as Ataxia teleangiectasia or similar, disorder or mental diseases, anticipated difficulties with carrying out brachytherapy $[3,6,10,11]$.

Table 1. Spatial pattern of ipsilateral breast relapse (IBTR) in patients enrolled in randomised trials testing the effect of whole breast radiotherapy [11]

\begin{tabular}{|c|c|c|c|}
\hline $\begin{array}{l}\text { Trial (time of primary } \\
\text { treatment) }\end{array}$ & $\begin{array}{l}\text { Median follow-up } \\
\text { (range) }\end{array}$ & $\begin{array}{l}\text { Recurrence number/ } \\
\text { Total number } \\
\text { of patients }\end{array}$ & Pattern of IBTR \\
\hline NSABP B-06 (1976-1984) [12] & 39 (5-95) months & $110(1108)$ & $\begin{array}{l}86 \% \text { within or close to the quadrant } \\
\text { of the index cancer } \\
14 \% \text { more diffuse within the breast }\end{array}$ \\
\hline Uppsala-Orebro (1981-1988) [13] & 10 years & $57(381)$ & $\begin{array}{c}69 \% \text { in the surgical field } \\
3.6 \% \text { in the cuticular scar } \\
3.6 \% \text { in the skin overlying the surgical field } \\
23.6 \% \text { in the breast parenchyma outside } \\
\text { the field of surgery }\end{array}$ \\
\hline $\begin{array}{l}\text { Ontario Clinical Oncology Group } \\
(1984-1989)[14]\end{array}$ & 43 months & $131(837)$ & $86 \%(83 \%$ with RT) at the site of primary surgery \\
\hline Milan III (1987-1989) [15] & 9 years & $75(579)$ & $\begin{array}{l}\text { 85\% (84\% with RT) in the scar area } \\
15 \%(16 \% \text { with RT) in other quadrants }\end{array}$ \\
\hline SweBCG 91-RT (1991-1997) [16] & 5 years & 104 (1178) & $\begin{array}{l}90 \% \text { in the same quadrant as the previous tumour } \\
10 \% \text { in other quadrants }\end{array}$ \\
\hline
\end{tabular}


Table 2. Spatial pattern of ipsilateral breast relapse (IBTR) in patients treated with breast conserving surgery plus whole breast radiotherapy [11]

\begin{tabular}{|c|c|c|c|c|}
\hline Authors, studies & $\begin{array}{l}\text { Median follow-up } \\
\text { (range) }\end{array}$ & $\begin{array}{l}\text { Local recurrence } \\
\text { rate (\%) }\end{array}$ & $\begin{array}{l}\text { Recurrence rate } \\
\text { outside of treated } \\
\text { quadrant (\%) }\end{array}$ & $\begin{array}{c}\text { Recurrence rate } \\
\text { in second breast (\%) }\end{array}$ \\
\hline \multicolumn{5}{|c|}{ Retrospective clinical trials (BCS + EBRT) } \\
\hline Kurtz et al. [17] & $11(5-24)$ years & 11 & 2 & 6 \\
\hline \multirow[t]{3}{*}{ Freedman et al. [18] } & 5 years & 3 & 1 & 3 \\
\hline & 10 years & 7 & 2 & 7 \\
\hline & 15 years & 13 & 6 & 13 \\
\hline \multirow[t]{3}{*}{ Krauss et al. [19] } & 5 years & 2 & 0.1 & 4 \\
\hline & 10 years & 7 & 2 & 9 \\
\hline & 15 years & 10 & 3 & 12 \\
\hline Veronesi et al. [20] & 8.5 years & 6.8 & 1.4 & 5 \\
\hline \multicolumn{5}{|c|}{ Prospective trials $(\mathrm{BCS}+\mathrm{EBRT})$} \\
\hline NSABP B-06 [21] & 39 (5-95) months & 2.7 & 0.7 & 9.4 \\
\hline Uppsala-Orebro trial [13] & 10 years & 8.5 & 2.1 & 10.5 \\
\hline Scottish trial [22] & 5.7 years & 5.8 & 1.4 & 1 \\
\hline Milan III [15] & 9 years & 5.4 & 1.3 & 3.4 \\
\hline NSABP B-21 [23] & 8 years & 9.3 & 2.3 & 5.4 \\
\hline SweBCG 91-RT [16] & 61 (10-98) months & 4.4 & 1.1 & 3.4 \\
\hline GBCSG trial [24] & 5.9 years & 4.2 & 1 & 2.1 \\
\hline ABCSG study 8 [25] & 53.8 months & 0.5 & 0.1 & 0.5 \\
\hline
\end{tabular}

$B C S$ - Breast Conserving Surgery, EBRT - External Beam Radiation Therapy

Table 3. American Brachytherapy Society and American Society of Breast Surgeons selection criteria and the Eligibility Criteria for NSABP B-39/RTOG 0413 Trial [31]

$\begin{array}{lccc} & \text { ABS } & \text { ASBS } & \text { NSABP B-39 } \\ \text { RTOG 0413 }\end{array}$

\section{APBI techniques}

In APBI currently are applied several techniques: 1) Interstitial brachytherapy (HDR, PDR, permanent implants); 2) Brachytherapy using the balloons (Mammosite, Contura,); 3) Hybrid brachytherapy devices (SAVI applicator); 4) External beam radiotherapy (3D, IMRT); 5) IORT (intraoperative radiotherapy) with electrons or X-rays. Below we will discuss the basic principles of brachytherapy techniques.

\section{Patient qualification for brachytherapy techniques}

Before preparing the treatment plan, a careful evaluation of tumor size and location should be made (clinical ex- amination, mammography, ultrasonography (US), magnetic resonance (MRI)), determination of the stage of disease according to TNM and detailed histopathological examination should be performed. In the course of conservative treatment it is advisable to leave 4 to 6 clips on the border of tissue removed in the axis of anterior-posterior, posterio-medial, sagittal, up and down, which will facilitate the preparation of the brachytherapy treatment plan. Clipping of tumor bed is considered by many authors as the most precise factor determining the accuracy of brachytherapy. In the treatment planning using BT are also helpful: description of surgical procedures specifying the location of the scar in relation to the tumor bed, postoperative mammography, occasionally X-ray image of the tumor bed or postoperative ultrasound. 
Table 4. GEC-ESTRO recommendations on patient selection for accelerated partial-breast irradiation [32]

\begin{tabular}{|c|c|c|c|}
\hline Characteristic & $\begin{array}{l}\text { A) Low-risk group - } \\
\text { good candidates for APBI }\end{array}$ & $\begin{array}{l}\text { B) Intermediate-risk group - } \\
\text { possible candidates for APBI }\end{array}$ & $\begin{array}{l}\text { C) High-risk group - } \\
\text { contraindication for APBI }\end{array}$ \\
\hline Age & $>50$ years & $40-50$ years & $<40$ years \\
\hline Histology & $\begin{array}{l}\text { IDC, mucinous, tubular, medullary, } \\
\text { and colloid cc. }\end{array}$ & $\begin{array}{l}\text { IDC, ILC, mucinous, tubular, } \\
\text { medullary, and colloid cC }\end{array}$ & - \\
\hline ILC & not allowed & not allowed & - \\
\hline Associated LCIS & allowed & allowed & - \\
\hline DCIS & not allowed & allowed & - \\
\hline $\mathrm{HG}$ & any & any & - \\
\hline Tumour size & pT1-2 (<30 mm) & $\mathrm{pT} 1-2(<30 \mathrm{~mm})$ & pT2 (> 30 mm), pT3, T4 \\
\hline Surgical margin & negative (> $2 \mathrm{~mm}$ ) & negative, but close $(<2 \mathrm{~mm})$ & positive \\
\hline Multicentricity & unicentric & unicentric & multicentric \\
\hline Multifocality & unifocal & $\begin{array}{l}\text { multifocal (limited within } 2 \mathrm{~cm} \\
\text { of the index lesion) }\end{array}$ & $\begin{array}{l}\text { multifocal (>2 cm from } \\
\text { the index lesion) }\end{array}$ \\
\hline EIC & not allowed & not allowed & present \\
\hline LVI & not allowed & not allowed & present \\
\hline ER, PR status & any & any & - \\
\hline Nodal status & pNO (SLNB or ALND*) & pN1mi, pN1a (by ALND*) & $\begin{array}{c}\mathrm{pNx} \text {; PpN2a } \\
\text { (4 or more positive nodes) }\end{array}$ \\
\hline Neoadjuvant che & not allowed & not allowed & if used \\
\hline
\end{tabular}

APBI - accelerated partial-breast irradiation; IDC - invasive ductal carcinoma; ILC - invasive lobular carcinoma; LCIS - lobular carcinoma in situ; DCIS - ductal carcinoma in situ; HG - histologic grade; EIC - extensive intraductal component; LVI - lympho-vascular invasion; ER - estrogen receptor; PR - progesterone receptor; $S L N B$ - sentinel lymph node biopsy *ALND - axillary lymph node dissection (at least 6 nodes pathologically examined)

\section{Interstitial multicatheter brachytherapy}

Currently, two brachytherapy techniques are used in breast cancer brachytherapy: HDR (high dose rate) and PDR (pulsed dose rate). Some clinical studies are published on using permanent implants $\left(\mathrm{I}^{125}, \mathrm{Pd}^{103}\right)[33,34]$.

\section{Techniques}

Perioperative application of catheters

Brachytherapy using interstitial applicators can be performed in two ways. Perioperative brachytherapy involves the assumption of flexible applicators during surgery in place of the tumor bed. In this method, BT is applied immediately during BCS. The advantage of a perioperative technique is a need for only one general anesthesia (implantation of applicators takes place during surgery), resulting in reducing overall treatment time and the ability to precisely determining the location of the tumor visible during surgery. Throughout lumpectomy/quadrantectomy, the surgeon provides surgical clips (should be 6) to determine the tumor bed (the clips are helpful later in treatment planning). Applying of applicators requires precision, experience and basic knowledge in the field of radiation from the surgeon. The limitation of perioperative "boost" is the lack of the final histopathological examination - the risk of incorrect BT qualification can be leveled by precise clinical staging before procedure, intraoperative histological examination and the necessary implementation of the Sentinel-Lymph-Node Biopsy (SNL). The irradiated area is limited to the surgical bed with $1-1.5 \mathrm{~cm}$ margin depending on technique.

\section{Application of catheters after BCS}

Applicators are often implanted after healing of the surgical scar and after receiving the final histopathological diagnosis in 2-4 weeks after surgery. Radiation oncologist inserts applicators after visualization of the tumor bed using $X$-ray (the location of surgical clips) and ultrasound (in general) or local anesthesia (depending on the experience of the center). Location of applicators on the skin with subcutaneous tissue and part of the breast is anesthetized with lidocaine or Xylocaine (2\%) solution, while analgesics are intravenously administered. General anesthesia involves standard procedures. After determining the shape and position of the tumor bed, the correct template and number of planes is selected, as well as the distance between the ap-

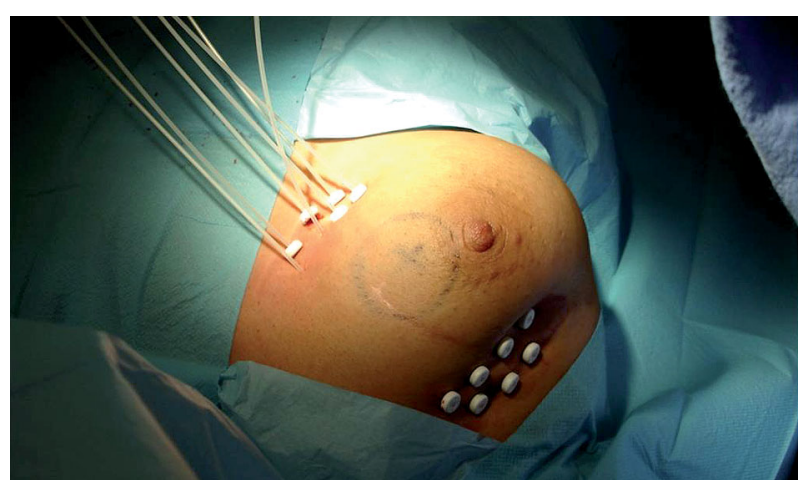

Fig. 2. Interstitial brachytherapy for breast cancer - implantation of 7 flexible applicators attached to the skin with buttons, the tumor bed localized by ultrasound 


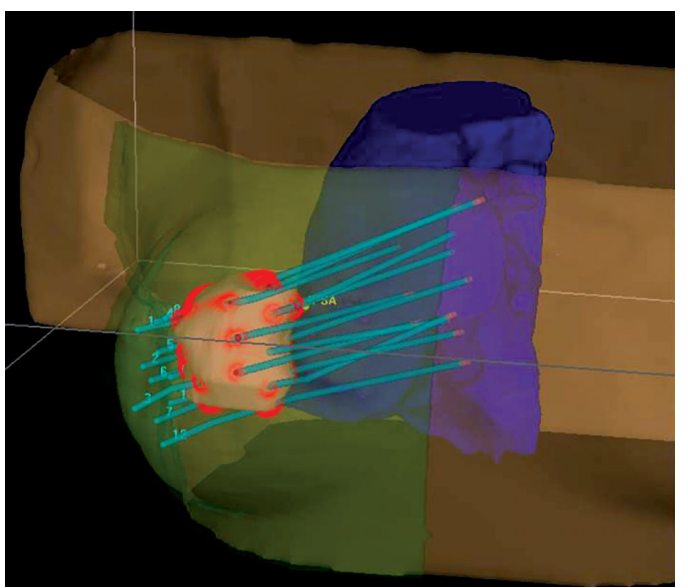

Fig. 3. Example of 3D treatment plan for breast cancer, indicating target, applicators, and critical organs (plan prepared by Oncentra Prostate ${ }^{\circledR}$ )

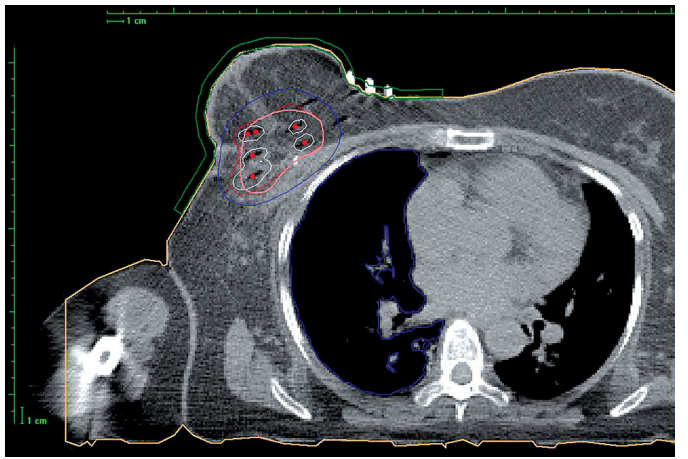

Fig 4. The distribution of dose (isodoses) obtained after the preparation of the treatment plan, target CT cross-sections performed every 2-3 $\mathrm{mm}$

A

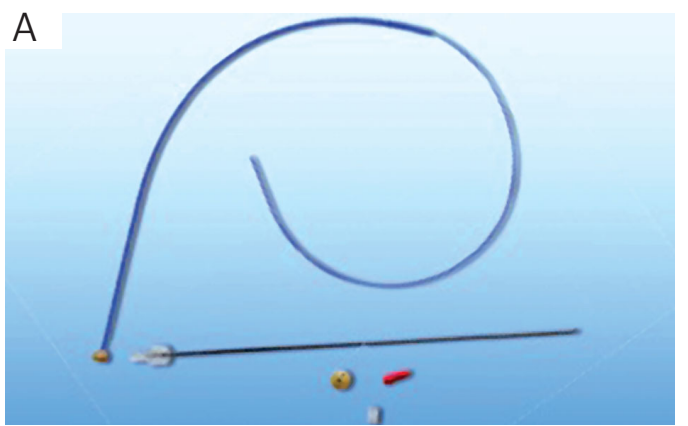

B

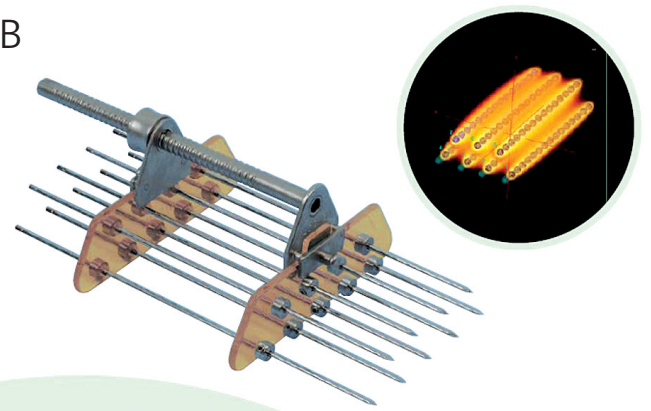

Fig. 5. Examples of applicators used in interstitial brachytherapy, A) from Varian Medical Systems (Breast Catheter Kits), B) from Nucletron Applicator Guide (Breast Template Set "Rabbit") plicators and the active length for stepping source. The number of implanted applicators has to be determined individually, depending on breast size, location of the tumor bed and type of surgery (tumorectomy, quadrantectomy). Frequently it is from 7 to over a dozen. Figure 2 shows images of applicators implanted in a patient with breast cancer after quadrantectomy, covering the upper external quadrant. Figures 3-5 present examples of treatment plan and applicators used in interstitial BT.

\section{Balloon brachytherapy (MammoSite, Contura) and hybrid SAVI applicators}

This technique was intended to reduce the technical difficulties associated with EBRT treatment planning and application of many interstitial applicators. The balloon applicator consists of a silicone balloon catheter, containing a channel for filling the balloon and 1 to 8 channels to introduce radioisotope (Figs. 6A-B, 7A-B). SAVI applicator does not include a balloon, but only applicators to adapt to the shape of the box (Figs. 8A-D). Balloon technique in principle is applicable in APBI without WBRT after surgery. HDR sources are used in this technique. Balloon applicators may be placed in the bed of the tumor during the BCS (rarely) or 2-4 weeks after surgery with the help of ultrasound. Previously published results suggest a satisfactory treatment outcome (as measured by the percentage of local failure) and good cosmetic results ( $80 \%$ to $93 \%$ of patients) [36-43]. So far, we do not have randomized studies comparing this technique treatment with interstitial BT.
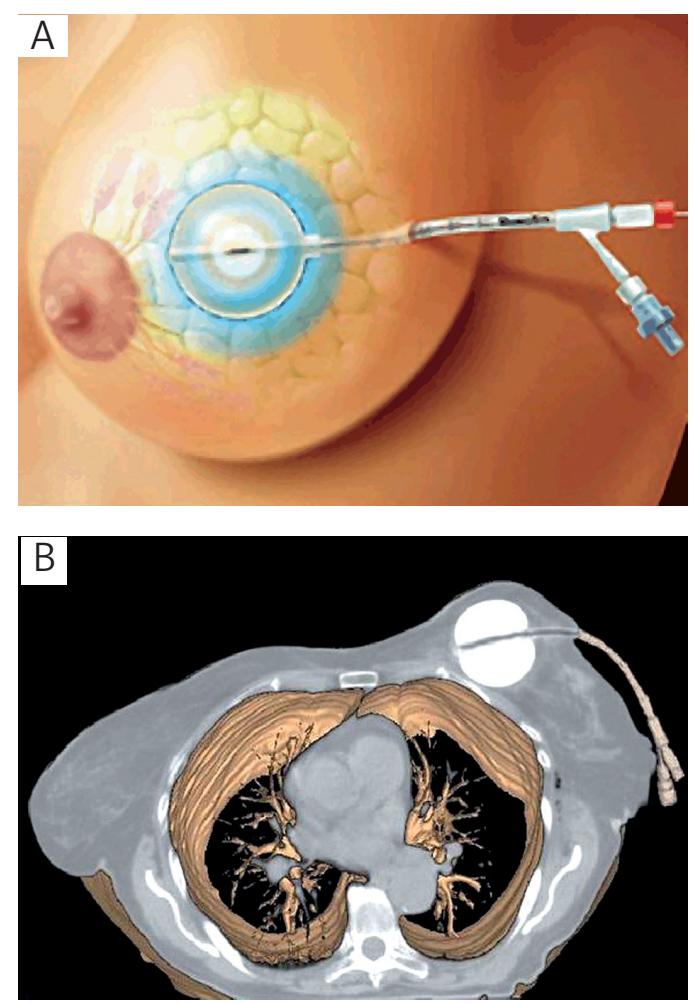

Fig. 6. A) MammoSite device used in balloon brachytherapy (Hologic ${ }^{\circledR}$, Marlborough). B) MammoSite balloon applicator in CT cross section with the indication of lung 
A
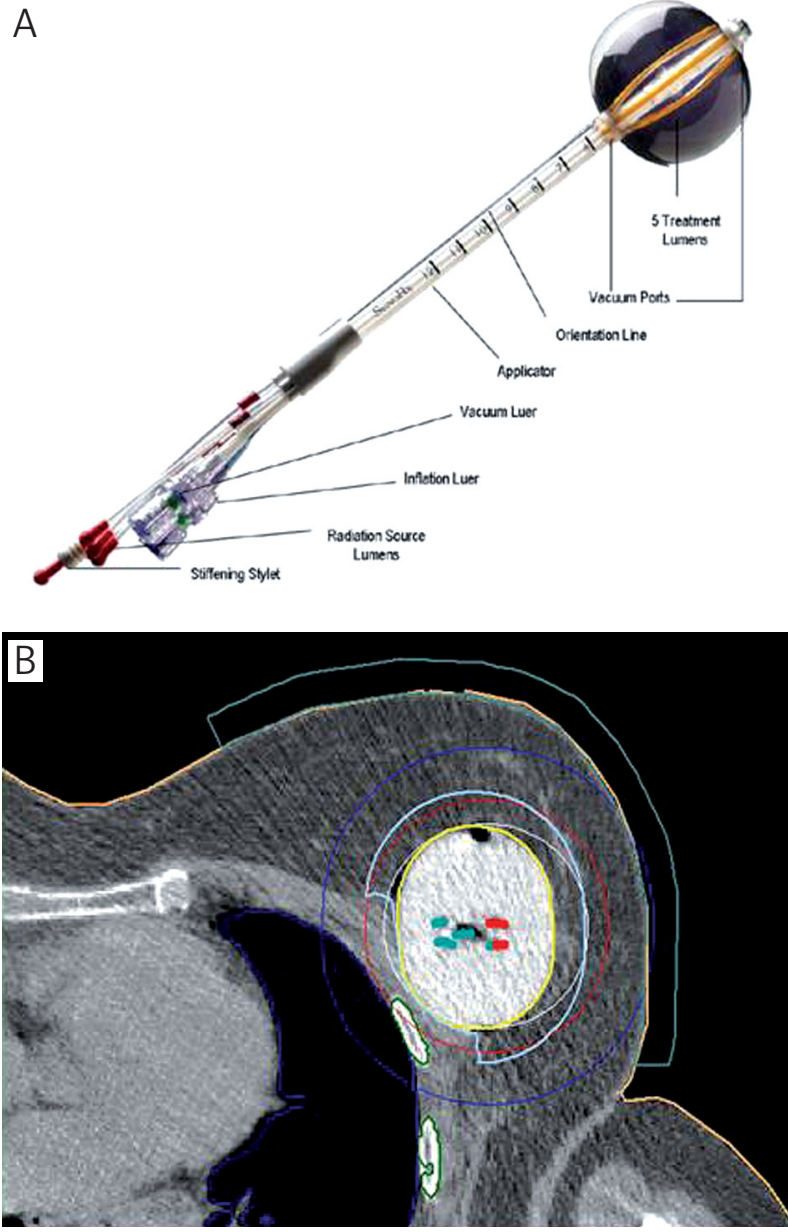

Fig. 7. A) Contura balloon applicator (SenoRx $\left.x^{\circledR}\right)$ [30]. B) Contura balloon applicator on CT section with the distribution of isodoses, 5 channels for iridium visible

The possible response will bring the results of Phase III Trial (NSABP B-39/RTOG 0413) conducted by the National Surgical Adjuvant Breast and Bowel Project (NSABP) and the Radiation Therapy Oncology Group (RTOG). The objective of this trial is to compare the results of different treatment methods: WBRT, APBI with MammoSite or multicatheter interstitial BT 3D EBRT in stage 0, I and II of breast cancer [38].

Balloon brachytherapy was developed as an alternative to interstitial brachytherapy. Interstitial brachytherapy requires the experience in setting up many interstitial applicators, while using balloon brachytherapy is simpler in the application. Cosmetic results after balloon brachytherapy techniques seem to be very acceptable $[37,40,43-45]$ with a high rate of satisfactory or excellent results. To achieve such results, the proper selection of patients (large breasts, central location of the primary tumor) is significant.

\section{Technique}

The balloon applicator consists of a silicone balloon with catheter to fill the balloon with fluid and 1 to 8 channels, where a radioactive source is placed. For the greater precision, in most centers using this method, the balloon is fixed
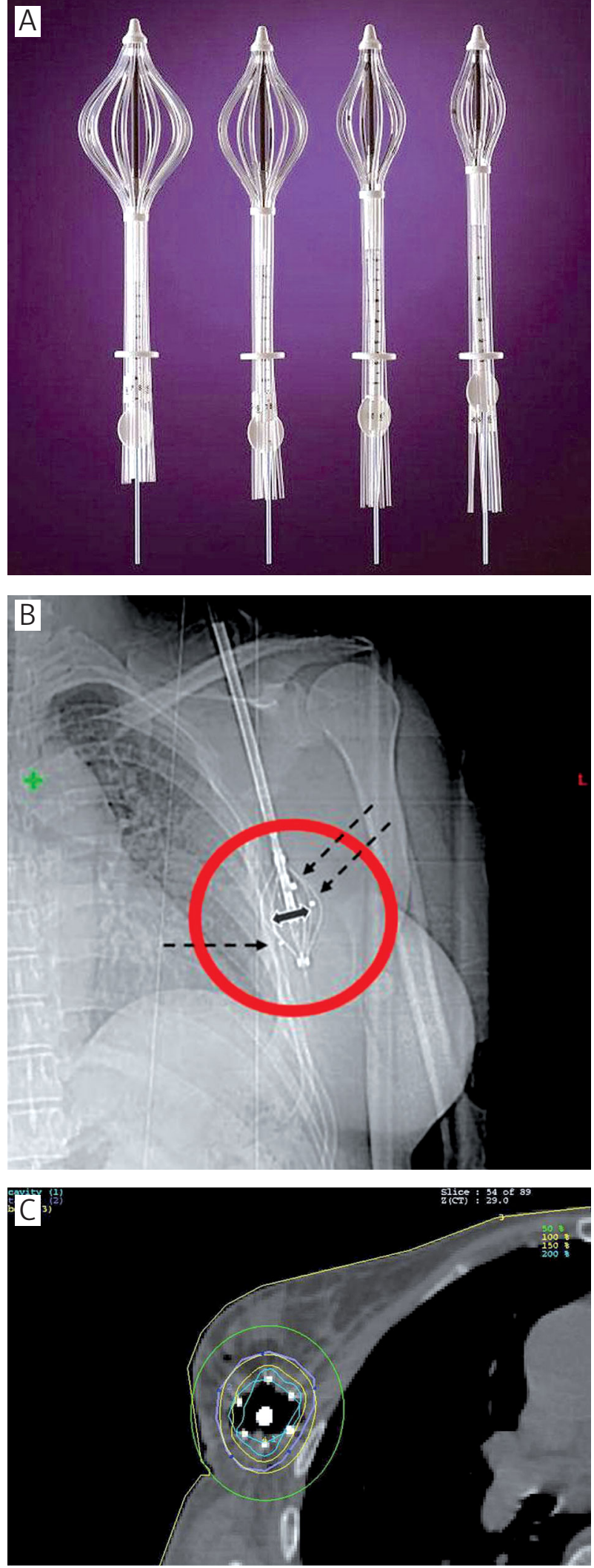

Fig. 8. A) Applicator SAVI (Strut Adjusted Volume Implant) with expanded channels (Cianna Medical ${ }^{\circledR}$ ) [30]. B) SAVI applicator X-ray images showing surgical clips (arrows) [35]. C) SAVI applicator, a balloon with a visible isodoses [35] 
A

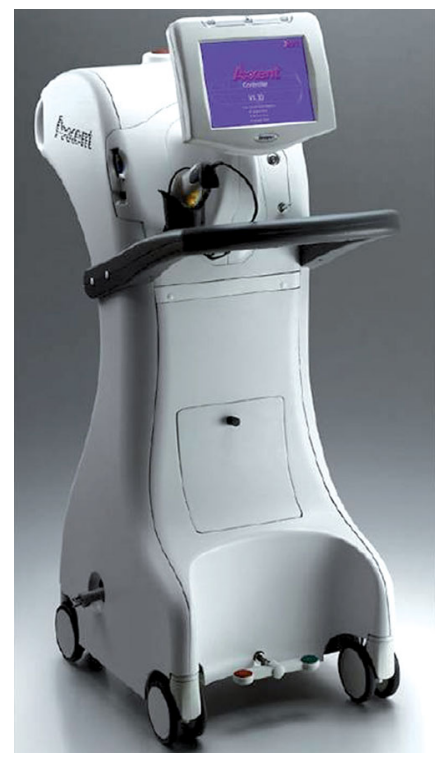

B

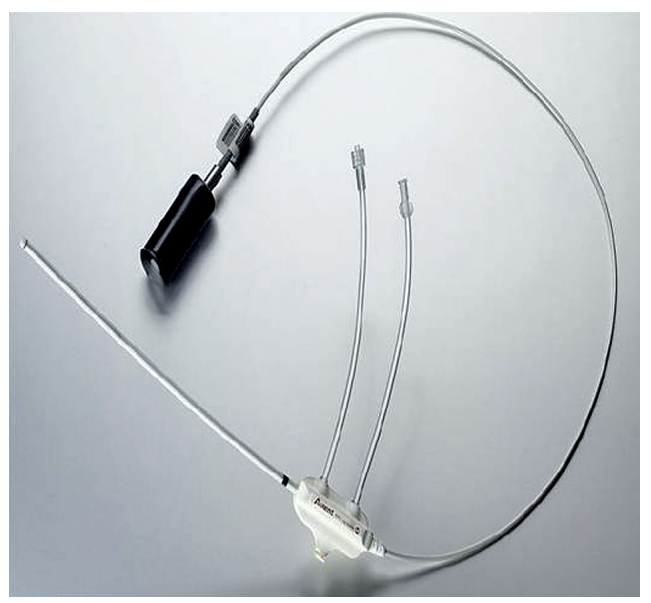

C

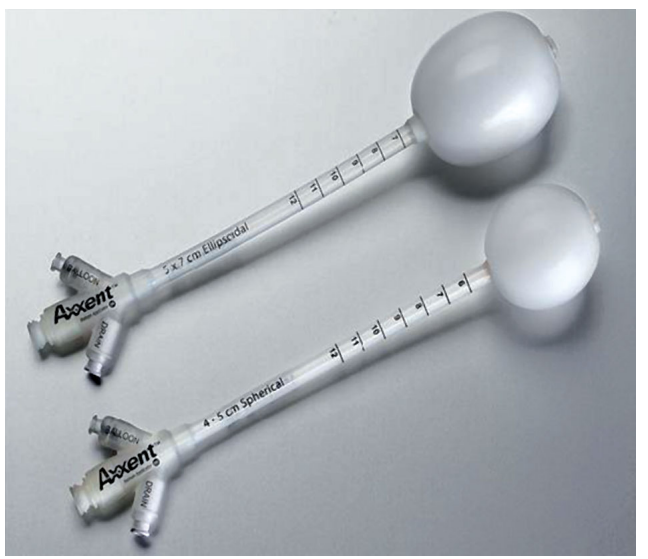

Fig. 9. A) Axxent Electronic Brachytherapy System, the control unit $\left(\mathrm{Xoft}^{\circledR}\right)$ [30]. B) Axxent Electronic Brachytherapy System, X-ray source HDR $\left(\mathrm{Xoft}^{\circledR}\right)$ [30]. C) Axxent Electronic Brachytherapy System, a balloon applicator $\left(\mathrm{Xoft}^{\circledR}\right)$ [30]

in the operating room under ultrasonography. Then the applicator is fluid-filled to a volume strictly adhering to the walls of the tumor bed. Afterwards, a cross-section CT is made in order to prepare a treatment plan. Target (CTV) in- cludes the volume of the balloon with a margin of $1 \mathrm{~cm}$. Critical organs include the skin and lungs. In this technique HDR sources are used.

\section{Doses}

The most common treatment schemas of APBI techniques are: 1) fraction dose of 3.4 Gy two times daily with an interval of 6 hours, 10 fractions in 5 days to a total dose of $34 \mathrm{~Gy}$; 2) fraction dose of 4 Gy two times daily -8 fractions to $32 \mathrm{~Gy} ; 3$ ) fraction dose of 4.3 Gy two times daily -7 fractions to 30.1 Gy $[31,32]$.

\section{Electronic brachytherapy [30]}

A platform for delivering HDR brachytherapy radiation has been developed that involves the electronic generation of $\mathrm{kV} X$-rays instead of using a radioactive source. The Axxent X-Ray Source manufactured by Xoft, Inc. was approved by the FDA for the treatment of breast cancer in January 2006 (Figs. 9A-C). The Xoft Axxent produces X-rays ranging from 20 to $50 \mathrm{kV}$, although only the $50 \mathrm{kV} \mathrm{X-ray} \mathrm{set-}$ ting is used in breast brachytherapy. Using the $50 \mathrm{kV}$ setting, the average energy of the $\mathrm{X}$-rays is $28 \mathrm{keV}$; the radial dose function lies between those of ${ }^{125} \mathrm{I}$ and ${ }^{103} \mathrm{Pd}$ sources [46]. The Xoft Axxent Electronic Brachytherapy source is used in conjunction with a balloon applicator. The disposable source is intended to be used for a maximum of 10 fractions. Testing of the inter-source consistency performed by Rivard et al. shows that individual sources produce predictable energy spectra, anisotropy functions and radial dose functions. As such, independent dosimetric verification is not necessary for each source. Instead, prior to each treatment, a single measurement of the source air-kerma strength is the only requirement [46].

The low energy photons emitted from the $\mathrm{kV}$ brachytherapy source $(\mathrm{KVB})$ have a limited range that obviates the need for a shielded radiation vault. This expands the settings in which the source could be used and may increase the availability of PBI. Additionally, the difference in photon energy between a KVB source and an ${ }^{192}$ Ir source has dosimetric implications. Dickler et al. found that the \% V90 and \%V100 do not appear to differ between KVB and MammoSite, demonstrating that KVB offers comparable target volume coverage. Due to its rapid dose fall-off, KVB provides a mean ipsilateral lung $\% \mathrm{~V} 30$ of $1.1 \%$ compared to $3.7 \%$ for MammoSite. Using KVB, the volume of the PTV receiving $200 \%$ of the prescription dose slightly exceeded the volume associated with an increased risk of fat necrosis in a previous study by Wazer et al. [44]. Similarly, a phantom study of KVB by Smitt et al. found that in order to achieve $90 \%$ coverage of the PTV, the V200 varied from 16 to $22 \mathrm{~cm}^{3}$ [48]. These figures are far higher than those of MammoSite and approach the dose-volume constraints that have been shown to be correlated with fat necrosis in studies of interstitial multicatheter brachytherapy [49]. However, it is unclear if dosimetric parameters that predict fat necrosis in multicatheter procedures are applicable to balloon applicator procedures. The effect of chemotherapy on the development of fat necrosis also remains to be clarified. 
Table 5. Comparison of APBI techniques - from Offersen [29] and Sarin [50]

\begin{tabular}{|c|c|c|c|c|c|}
\hline & 3D EBRT & $\begin{array}{l}\text { Interstitial } \\
\text { brachytherapy } \\
\text { HDR, LDR, PDR }\end{array}$ & MammoSite & $\begin{array}{c}\text { Targit, } 50 \text { kV } \\
\text { X-rays }\end{array}$ & IORT, electrons \\
\hline Coverage of target & best & good & good & good & good \\
\hline $\begin{array}{l}\text { Thickness } \\
\text { of cavity wall } \\
\text { irradiated }\end{array}$ & $\begin{array}{l}\text { PTV }=\text { tumor } \\
\text { bed }+20-25 \mathrm{~mm} \\
\text { often } 5 \mathrm{~mm} \\
\text { to field edge } \\
\text { from PTV }\end{array}$ & $1-2 \mathrm{~cm}$ & $\begin{array}{c}\text { dose prescribed } \\
\text { to } 1 \mathrm{~cm} \text { from surface } \\
\text { of applicator }\end{array}$ & $\begin{array}{l}\text { dose prescribed } \\
\text { to } 1 \mathrm{~mm} \text { from surface } \\
\text { of applicator. } \\
5-7 \mathrm{~Gy} 10 \mathrm{~mm} \\
\text { from applicator }\end{array}$ & $\begin{array}{c}\text { dose prescribed to } 90 \% \\
\text { isodose line. } 80 \% \text { isodose } \\
\text { at } 13 \mathrm{~mm}(3 \mathrm{MeV})- \\
24 \mathrm{~mm}(9 \mathrm{MeV})\end{array}$ \\
\hline $\begin{array}{l}\text { Dose } \\
\text { homogeneity }\end{array}$ & best & fair & fair & fair & fair \\
\hline $\begin{array}{l}\text { Sparing of normal } \\
\text { breast/other } \\
\text { organs }\end{array}$ & least & good & good & best & varies with location \\
\hline Skin dose & least & least & variable & least (can shield) & least \\
\hline $\begin{array}{l}\text { Technical feasibility } \\
\text { for various size, } \\
\text { shape or location } \\
\text { of cavity }\end{array}$ & $\begin{array}{l}\text { suitable for } \\
\text { virtually } \\
\text { all cases }\end{array}$ & $\begin{array}{c}\text { not suitable } \\
\text { if inadequate } \\
\text { tissue or near } \\
\text { axilla }\end{array}$ & $\begin{array}{c}\text { not suitable } \\
\text { for large/irregular } \\
\text { cavities, or at the } \\
\text { periphery } \\
\text { of the breast }\end{array}$ & $\begin{array}{l}\text { not suitable for } \\
\text { large/irregular } \\
\text { cavities, or at the } \\
\text { periphery of the } \\
\text { breast }\end{array}$ & $\begin{array}{c}\text { not suitable for tumors } \\
\text { near brachial } \\
\text { lexus/axilla or skin }\end{array}$ \\
\hline Expertise required & average & high & average & high & very high \\
\hline $\begin{array}{l}\text { Potential for } \\
\text { wide spread use }\end{array}$ & very good & fair & very good & fair & limited \\
\hline Main drawback & $\begin{array}{l}\text { relatively higher } \\
\text { dose to normal } \\
\text { tissue and } \\
\text { breathing } \\
\text { motion }\end{array}$ & $\begin{array}{c}\text { adequacy } \\
\text { of target } \\
\text { overage in some } \\
\text { cases and wider } \\
\text { applicability }\end{array}$ & $\begin{array}{c}\text { cavity shape } \\
\text { and size. Although } \\
\text { easy to use, } \\
\text { stringent QA } \\
\text { is required. Skin } \\
\text { dose may be high }\end{array}$ & $\begin{array}{l}\text { very limited depth } \\
\text { irradiated; cavity } \\
\text { shape and size, } \\
\text { histology not } \\
\text { available }\end{array}$ & $\begin{array}{c}\text { wider applicability. } \\
\text { Histology not available, } \\
\text { based on quadrantec- } \\
\text { tomy }\end{array}$ \\
\hline
\end{tabular}

Table 6. Results of recent clinical experience with interstitial brachytherapy with more than 5 years follow-up [30]

\begin{tabular}{|c|c|c|c|c|c|c|c|}
\hline Author & $\begin{array}{l}\text { No of } \\
\text { cases }\end{array}$ & $\begin{array}{c}\text { Follow up } \\
\text { interval (years) }\end{array}$ & Technique & Scheme & Total dose (Gy) & $\begin{array}{l}\text { 5-year } \\
\text { LR (\%) }\end{array}$ & $\begin{array}{l}\text { Good/Excellent } \\
\text { cosmesis }\end{array}$ \\
\hline $\begin{array}{l}\text { Strnad } \\
\text { et al. [51] }\end{array}$ & 274 & 5.25 & $\mathrm{PDR} / \mathrm{HDR}$ & $\begin{array}{l}\text { PDR - } 0.6 \text { Gy/h } \\
\text { HDR - } 4 \text { Gy × } 8 \text { fr. }\end{array}$ & $\begin{array}{l}\mathrm{PDR}=50 \mathrm{~Gy} \\
\mathrm{HDR}=32 \mathrm{~Gy}\end{array}$ & $2.9 \%$ & $90 \%$ \\
\hline $\begin{array}{l}\text { Antonucci } \\
\text { et al. [52] }\end{array}$ & 199 & 9.6 & LDR/HDR & $\begin{array}{c}\mathrm{LDR}-0.52 \mathrm{~Gy} / \mathrm{h} \times 96 \mathrm{~h} \\
\text { HDR }-4 \mathrm{~Gy} \times 8 \mathrm{fr} \\
\text { HDR }-3.4 \mathrm{~Gy} \times 10 \mathrm{fr} .\end{array}$ & $\begin{array}{l}\mathrm{LDR}=50 \mathrm{~Gy} \\
\mathrm{HDR}=32 \mathrm{~Gy} \\
\mathrm{HDR}=34 \mathrm{~Gy}\end{array}$ & $5 \%$ & $99 \%$ \\
\hline $\begin{array}{l}\text { Johansson } \\
\text { et al. [53] }\end{array}$ & 50 & 7.2 & PDR & $\mathrm{HDR}-50 \mathrm{~Gy} / 5 \mathrm{~d}$ & $50 \mathrm{~Gy}$ & $4 \%$ & $56 \%$ \\
\hline $\begin{array}{l}\text { Arthur } \\
\text { et al. [54] }\end{array}$ & 99 & 7 & LDR/HDR & $\begin{array}{c}\mathrm{LDR}-3.5 \mathrm{~Gy} / 5 \mathrm{~d} \\
\mathrm{HDR}-3.4 \mathrm{~Gy} \times 10 \mathrm{fr}\end{array}$ & $\begin{array}{l}45 \text { Gy (LDR) } \\
34 \text { Gy (HDR) }\end{array}$ & $4 \%$ & $\mathrm{n} / \mathrm{a}$ \\
\hline $\begin{array}{l}\text { Polgar } \\
\text { et al. [55] }\end{array}$ & 128 & 6.8 & HDR & HDR - $5.2 \mathrm{~Gy} \times 7 \mathrm{fr}$ & 36.4 Gy & $4.7 \%$ & $77 \%$ \\
\hline $\begin{array}{l}\text { King } \\
\text { et al. [56] }\end{array}$ & 51 & 6.25 & LDR/HDR & $\begin{array}{c}L D R-4 d \\
H D R-4 G y \times 8 f r .\end{array}$ & $\begin{array}{l}45 \text { Gy (LDR) } \\
32 \text { Gy (HDR) }\end{array}$ & $3.9 \%$ & $75 \%$ \\
\hline $\begin{array}{l}\text { Otto } \\
\text { et al. [57] }\end{array}$ & 274 & 5.25 & $\mathrm{PDR} / \mathrm{HDR}$ & $\begin{array}{l}\text { PDR - } 5 \mathrm{~d}, 0.6 \mathrm{~Gy} / \mathrm{h} \\
\mathrm{HDR}-4 \mathrm{~Gy} \times 8 \mathrm{fr}\end{array}$ & $\begin{array}{c}49.8 \text { Gy (PDR) } \\
32 \text { Gy (HDR) }\end{array}$ & $2.9 \%$ & $92 \%$ \\
\hline $\begin{array}{l}\text { Polgar } \\
\text { et al. [58] }\end{array}$ & 45 & 11.1 & HDR & $\begin{array}{l}\mathrm{HDR}-4.33 \mathrm{~Gy} \times 7 \mathrm{fr} . \\
\mathrm{HDR}-5.2 \mathrm{~Gy} \times 7 \mathrm{fr} .\end{array}$ & $\begin{array}{l}30.3 \mathrm{~Gy} \\
36.4 \mathrm{~Gy}\end{array}$ & $4.4 \%$ & $78 \%$ \\
\hline
\end{tabular}

$L R$ - local recurrence; HDR - high dose rate; $L D R$ - low dose rate; $P D R$ - pulsed dose rate; $n / a$ - data not available; $h$ - hours, $d$-days; fr. - fractions

\section{Results of APBI}

Comparison of different APBI techniques is posted in Table $5[29,50]$. Clinical results of APBI after various treat- ment techniques are presented in tables. Table 6 presents the results of interstitial brachytherapy, Tables 7,8 - results of balloon brachytherapy. 
Table 7. Some of the recent clinical experience with MammoSite [29]

\begin{tabular}{|c|c|c|c|c|c|}
\hline Institution & $\begin{array}{l}\text { APBI } \\
\text { technique }\end{array}$ & $\begin{array}{l}\text { No. of } \\
\text { cases }\end{array}$ & $\begin{array}{l}\text { Follow-up } \\
\text { (years) }\end{array}$ & $\begin{array}{l}\text { Inclusion criteria } \\
\text { and definition of target }\end{array}$ & $\begin{array}{l}\text { Ipsilateral breast } \\
\text { recurrence }\end{array}$ \\
\hline $\begin{array}{l}\text { American Society of Breast } \\
\text { Surgeons, MammoSite Breast } \\
\text { Brachytherapy Trial [59-64] }\end{array}$ & $34 \mathrm{~Gy} / 10 \mathrm{fr} / 5 \mathrm{~d}$ & 1255 & 2.5 & $\begin{array}{c}\text { > } 45 \text { years, T6 } 2 \mathrm{~cm} \text {, N0, negative } \\
\text { margins, ductal only, applicator } \\
\text { placement < } 10 \text { weeks postoperative, } \\
\text { cavityP3 cm in one dimension, no EIC, }\end{array}$ & $\begin{array}{l}2 \text { years }-1.11 \% \\
3 \text { years }-1.79 \%\end{array}$ \\
\hline $\begin{array}{l}\text { Texas Cancer Clinic } \\
\text { San Antonio [65] }\end{array}$ & $34 \mathrm{~Gy} / 10 \mathrm{fr} / 5-7 \mathrm{~d}$ & 67 & 1.1 & $\begin{array}{l}\geq 45 \text { years, } T<3 \mathrm{~cm}, \mathrm{~N} 0 \text {, negative } \\
\text { margins, lumpectomy cavity } 3-6 \mathrm{~cm}\end{array}$ & NA \\
\hline $\begin{array}{l}\text { Kaiser Pernamente Los Angeles } \\
\text { Medical Center }[66,67]\end{array}$ & $34 \mathrm{~Gy} / 10 \mathrm{fr} / 5-7 \mathrm{~d}$ & 51 & 1.3 & $\begin{array}{c}\geq 45 \text { years, } \mathrm{T} 62 \mathrm{~cm}, \mathrm{NO}, \\
\text { ductal only, negative margins }\end{array}$ & 0 \\
\hline $\begin{array}{l}\text { Rush University Medical } \\
\text { Center, Chicago }[68,69]\end{array}$ & $34 \mathrm{~Gy} / 10 \mathrm{fr} / 5-7 \mathrm{~d}$ & 78 & 2.2 & $\begin{array}{c}\geq 45 \text { years, } T<3 \mathrm{~cm}, \mathrm{NO}, \\
\text { negative margins }\end{array}$ & $7.1 \%$ \\
\hline $\begin{array}{l}\text { Medical University } \\
\text { of South Carolina [70] }\end{array}$ & $32 \mathrm{~Gy} / 10 \mathrm{fr} / 5-7 \mathrm{~d}$ & $\begin{array}{l}37 \text { (7 with } \\
\text { DCIS) }\end{array}$ & 0.5 & 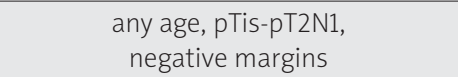 & NA \\
\hline $\begin{array}{l}\text { Tufts New England } \\
{[71,72]}\end{array}$ & $34 \mathrm{~Gy} / 10 \mathrm{fr} / 5-7 \mathrm{~d}$ & 38 & 1.4 & $\begin{array}{l}\text { any age, } T<3 \mathrm{~cm} \text {, ductal and DCIS, } \\
\text { NO (solitary nodal micrometastasis } \\
\text { accepted), negative margins }>1 \mathrm{~mm}\end{array}$ & NA \\
\hline $\begin{array}{l}\text { European MammoSite } \\
\text { trial }[73,74]\end{array}$ & $34 \mathrm{~Gy} / 10 \mathrm{fr} / 5-7 \mathrm{~d}$ & 28 & 1.2 & $\begin{array}{c}\geq 60 \text { years, } T \leq 2 \mathrm{~cm} \text {, ductal } \\
\text { only, grade } 1 / 2 \text {, margins }>5 \mathrm{~mm}, \\
\text { ER }+ \text {, balloon-skin distance }>7 \mathrm{~mm} \text {, } \\
\text { lumpectomy cavity }>3 \mathrm{~cm} \text {, no EIC }\end{array}$ & 0 \\
\hline
\end{tabular}

EIC - extensive intraductal component; DCIS - ductal carcinoma in situ; ER - estrogen receptor; PR - progesterone receptor; N/A - data not available; $d$ - days; fr-fractions

Table 8. Local recurrences after MammoSite [31]

\begin{tabular}{lccc} 
Trial & No. of cases & Follow-up (months) & Local recurrences rate (\%) \\
\hline ASBS TRIAL [75] & 1440 & 30 & 1.04 \\
\hline Tufts/Medical College Virginia/Rhode Island [71] & 28 & 19 & 0 \\
\hline St. Vincent Cancer Center [66] & 31 & 11 & 0 \\
\hline Rush University Medical Center [76] & 70 & 26 & 5.7 \\
\hline Kaiser Permanente [49] & 40 & 13 & 0 \\
\hline Medical University South Carolina [74] & 90 & 24 & 2.2 \\
\hline ASBS DCIS TRIAL [77] & 191 & 7 & 0 \\
\hline Wiliam Beaumont [68] & 80 & 22 & 2.5 \\
\hline European TRIAL [73] & 44 & 14 & 0 \\
\hline International TRIAL [78] & 23 & 20 & 0 \\
\hline Western Pensylwania Hospital [79] & 55 & 24 & 3.6 \\
\hline Oscar Lambret Center [69] & 25 & 13 & 0
\end{tabular}

Table 9. Rates of good and excellent cosmesis after MammoSite brachytherapy [31]

\begin{tabular}{lccc} 
Institution/Study & Number of patients & Follow-up (months) & Good or excellent cosmesis (\%) \\
\hline ASBS registry trial [63] & 1449 & 30 & 94 \\
\hline FDA trial [75] & 36 & 65 & 81 \\
\hline Tufts/medical college of Virginia/Rhode Island [46] & 28 & 19 & 93 \\
\hline St. Vincent's cancer center [66] & 31 & 11 & 86 \\
\hline Rush university medical center [76] & 30 & 26 & 93 \\
\hline Kaiser permanente [49] & 40 & 13 & 97 \\
\hline Medical University of South Carolina [74] & 90 & 24 & 90 \\
\hline ASBS DCIS trial [77] & 191 & 7 & 94 \\
\hline William Beaumont [68] & 80 & 22 & 88 \\
\hline European trial [73] & 44 & 14 & 75 \\
\hline International trial [78] & 18 & 20 & 67 \\
\hline Oscar Lambret center [69] & 25 & 13 & 84
\end{tabular}


Table 10. Cosmesis and complications after APBI with interstitial brachytherapy [29]

\begin{tabular}{|c|c|c|c|c|}
\hline Institution & Technique & $\begin{array}{l}\text { Number } \\
\text { of patients }\end{array}$ & Follow-up & Cosmesis and complications \\
\hline $\begin{array}{l}\text { The William } \\
\text { Beaumont } \\
\text { Hospital, USA } \\
{[49,80-82]}\end{array}$ & $\begin{array}{l}\text { HDR } 32-34 \text { Gy/8-10 fr/4-5 days } \\
\text { LDR } 50 \text { Gy, } 96 \text { hours }\end{array}$ & 199 & $\begin{array}{c}5.7 \text { years }(L R) \\
6.4 \text { years (cosmesis) }\end{array}$ & $\begin{array}{l}7 \% \text { acute infection, } 4 \% \text { late infection, } \\
11 \% \text { fat necrosis at } \geq 5 \text { years } \\
\text { good/excellent cosmesis } b \text { in }>90 \%\end{array}$ \\
\hline $\begin{array}{l}\text { Ochsner Clinic, } \\
\text { USA [83] }\end{array}$ & $\begin{array}{l}\text { HDR 32-34 Gy/8-10 fr/ } \\
\text { 4-5 days } \\
\text { LDR } 45 \text { Gy, } 4 \text { days }\end{array}$ & 50 & 6.3 years & $\begin{array}{l}\text { cosmesis scored at median } 20 \text { months: } \\
22 \% \text { grade I/II compl., } \\
8 \% \text { grade III compl., } 75 \% \text { had an excellent/ } \\
\text { good cosmesis }{ }^{a} \text {, all based on }{ }^{a}\end{array}$ \\
\hline $\begin{array}{l}\text { Ochsner Clinic, } \\
\text { USA [84] }\end{array}$ & $\begin{array}{l}\text { HDR 32-34 Gy/8-10 fr/4-5 days } \\
\text { LDR } 45 \text { Gy, } 4 \text { days }\end{array}$ & 99 & 2.7 years & $\begin{array}{l}\text { late grade III tox. } 18 \%(\mathrm{LDR}) \text { and } 4 \% \text { (HDR), } \\
\text { no late grade IV tox., all based on }{ }^{\mathrm{a}}\end{array}$ \\
\hline $\begin{array}{l}\text { London Regional } \\
\text { Cancer Center, } \\
\text { Ontario [85] }\end{array}$ & HDR 37.2 Gy/10 fr/5 days & 39 & 7.6 years & $\begin{array}{l}\text { median overall cosmetics score } 89 \% \text {, } \\
13 \% \text { had fat necrosis }{ }^{a} \text {, all based on }{ }^{a}\end{array}$ \\
\hline $\begin{array}{l}\text { Tufts New England } \\
{[44,86-88]}\end{array}$ & HDR 34 Gy/10 fr/5 days & 75 & 6.1 years & 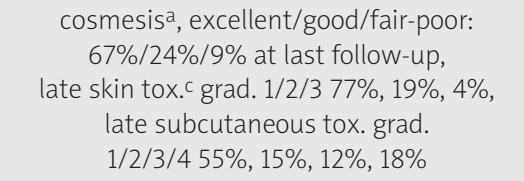 \\
\hline $\begin{array}{l}\text { Tufts New } \\
\text { England [89] }\end{array}$ & LDR 50, 55, and 60 Gy & 48 & 1.9 years & $\begin{array}{c}\text { very good/excellent cosmesis } 91.8 \% \text {, } \\
12.5 \% \text { perioperative complications, } \\
25 \% \text { had fibrosis, } 8 \% \text { moderate to severe } \\
\text { fibrosis, based ona }\end{array}$ \\
\hline $\begin{array}{l}\text { Tufts New } \\
\text { England [90] }\end{array}$ & HDR 34 Gy/10 fr/5 days & 32 & 7 years & $\begin{array}{l}18 \% \text { had fat necrosis }>5 \text { years, } \\
35.7 \% \text { moderate to severe subcutaneous } \\
\text { fibrosis }>5 \text { years, } 89 \% \text { excellent cosmesis at } \\
5 \text { years, toxicity based onc, fibrosis }>5 \text { years }\end{array}$ \\
\hline $\begin{array}{l}\text { University } \\
\text { of Kansas [91] }\end{array}$ & LDR 20-25 Gy & 24 & 3.9 years & $\begin{array}{c}\text { cosmesis good to excellent in } 100 \% \text {, } \\
\text { no late complications, based ona }\end{array}$ \\
\hline $\begin{array}{l}\text { Guys Hospital, } \\
\text { London }[92,93]\end{array}$ & LDR 55 Gy, 5 days & 27 & 6 years & $\begin{array}{l}\text { cosmesis good to excellent in } 83 \% \text {, } \\
\text { no fibrosis, based ona }\end{array}$ \\
\hline $\begin{array}{l}\text { Guys Hospital, } \\
\text { London [94] }\end{array}$ & LDR 45 Gy, 4 days & 49 & 6.3 years & abnormal breast in $58 \%$, based ona \\
\hline $\begin{array}{l}\text { National Institue } \\
\text { of Oncology, } \\
\text { Hungary }[95,96]\end{array}$ & HDR 30.3-36.4 Gy/7 fr/4 days & 45 & 6.8 years & $\begin{array}{l}\text { cosmesis excellent/good in } 84.4 \% \text {, } \\
\text { fat necrosis } 20 \%, \geq \text { grade } 2 \text { late radiation } \\
\text { reaction } 26.7 \% \text {, based on }{ }^{b}\end{array}$ \\
\hline $\begin{array}{l}\text { National Institue } \\
\text { of Oncology, } \\
\text { Hungary }[55,97]\end{array}$ & $\begin{array}{c}\text { HDR } 36.4 \mathrm{~Gy} / 7 \mathrm{fr} / 4 \text { days } \\
(n=88) \text { or ERBT } 50 \mathrm{~Gy} / 25 \mathrm{fr} \\
(n=40)\end{array}$ & 126 & 5.5 years & $\begin{array}{l}\text { excellent to good in } 81.2 \% \text { (HDR) and } 70 \% \\
\text { (electrons), based on }{ }^{\text {b }, 4-y e a r ~ a c t u a r i a l ~ f a t ~} \\
\text { necrosis } 36.5 \% \text { (HDR) and } 17.7 \% \text { (electrons), } \\
\text { based on institutional scheme }\end{array}$ \\
\hline $\begin{array}{l}\text { Erlangen, Germany } \\
{[57,98-100]}\end{array}$ & $\begin{array}{c}\text { HDR (36\%) } 32 \text { Gy/8 fr/5 days; } \\
\text { PDR (64\%) } 49.8 \text { Gy } \\
\text { in } 83 \text { consecutive fractions } \\
\text { of } 0.6 \text { Gy each hour/5 days }\end{array}$ & 274 & 2.7 years & $\begin{array}{l}\text { cosmesis excellent to good in } 94 \% \text {, } \\
\text { acute toxicity in } 6.6 \% \text {, fat necrosis } 4.7 \% \text {, } \\
\text { breast tissue fibrosis in } 19.3 \% \text { and telangiec- } \\
\text { tasia in } 12.8 \% \text {, scoring based onb,c,d }\end{array}$ \\
\hline
\end{tabular}

Number of patients refers to patients diagnosed with invasive cancera; Cosmesis scored according to institutional guidelines: $b$ Cosmesis scored according to Harvard criteria [101]; ' Skin and subcutaneous toxicity scored according to Radiation Therapy Oncology Group (RTOG)/Eastern Cooperative Oncology Group system [102];

${ }^{d}$ Acute and late side effects based on LENT SOMA [103]

\section{Cosmetic effect}

Cosmetic results after brachytherapy techniques seem to be very satisfactory. Draws attention a high rate of satisfactory or excellent results. Essential to achieve such results is a proper selection of patients (large breasts, the central location of the primary tumor).

The tables below provide a summary of cosmetic results after using the balloon brachytherapy and interstitial brachytherapy (Tables 9, 10).

\section{Conclusions}

The percentage of local recurrence and the cosmetic results are an important argument for the choice of APBI brachytherapy technique. Based on available results from prospective clinical trials where excellent results in selected groups of patients are achieved, it seems reasonable to use of APBI outside clinical trials in selected cases. These is a conclusion also of GEC-ESTRO Breast Cancer Working Group [32]. Strict criteria for selecting patients with early 
breast cancer group (low-risk group) and systematic quality control procedures (QA) must be preserved. These recommendations may be an indication for physicians and patients to choose an APBI techniques.

\section{References}

1. Jassem J (ed.). Rak sutka. Springer-PWN, Warszawa 1998 [in Polish].

2. Clarke DH, Vicini F, Jacobs $\mathrm{H}$ et al. High dose rate brachytherapy for breast cancer. In: Nag S (ed.). High dose rate brachytherapy: A textbook. Armonk Futura Publishing Company Inc., New York 1994, pp. 321-329.

3. Gerbaulet A, Potter R, Mazeron J-J et al. (eds.). The GEC ESTRO Handbook of Brachytherapy. ESTRO, Brussels 2002.

4. Sauer G, Strnad V, Kurzeder C et al. Partial Breast Irradiation after Breast-Conserving Surgery. Strahlenther Onkol 2005; 181: 1-8.

5. Makarewicz R (ed.). Brachyterapia HDR. Via Medica, Gdańsk 2004 [in Polish].

6. Polgar C, Major T, Somogyi A et al. Sole brachytherapy after breast conserving surgery: 4-years results of a pilot study and initial findings of a randomized Phase III trial (abstract). Radiother Oncol 2000; 55 (suppl. 1): 31.

7. Vicini F, Kini VR, Chen P. Brachytherapy of the tumour bed alone after lumpectomy in selected patients with early stage breast cancer treated with breast conserving therapy. J Surg Oncol 1999; 70: 30-40.

8. Kuske RR, Bolton JS, Mc Kinnon MP et al. 6.5-year results of a prospective phase II trial of wide volume brachytherapy as the sole method of breast irradiation in Tis, T1, T2, No1 breast cancer (abstract). Radiother Oncol 2000; 55 (suppl.1): 2.

9. Johansson B, Kalsson L, Liljegren G et al. PDR brachytherapy as the sole adjuvant radiotherapy after breast conserving surgery of T1-T2 breast cancer (abstract). In: Program \& Abstracts. $10^{\text {th }}$ International Brachytherapy Conference, Madrid, Nucletron 2000, pp. 127.

10. Niwińska A. Postępy w radioterapii: napromienianie części gruczołu piersiowego (Partial Breast Irradiation - PBI) $\mathrm{u}$ chorych na raka piersi po operacji oszczędzajacej. Nowotwory 2003; 6: 643-647 [in Polish].

11. Mannino M, Yarnold J. Accelerated partial breast irradiation trials: Diversity in rationale and design. Radiother Oncol 2009; 91: 16-22.

12. Fisher ER, Sass R, Fisher B et al. Pathologic findings from the National Surgical Adjuvant Breast Project (protocol 6). II. Relation of local breast recurrence to multicentricity. Cancer 1986; 57: 1717-1724.

13. Liljegren G, Holmberg L, Bergh J et al. 10-Year results after sector resection with or without postoperative radiotherapy for stage I breast cancer: a randomized trial. J Clin Oncol 1999; 17: 2326-2333.

14. Clark RM, Whelan $\mathrm{T}$, Levine $\mathrm{M}$ et al. Randomized clinical trial of breast irradiation following lumpectomy and axillary dissection for node-negative breast cancer: an update. Ontario Clinical Oncology Group. J Natl Cancer Inst 1996; 88: 1659-1664.

15. Veronesi U, Marubini E, Mariani L et al. Radiotherapy after breast-conserving surgery in small breast carcinoma: long-term results of a randomized trial. Ann Oncol 2001; 12: 997-1003.

16. Malmstrom P, Holmberg L, Anderson H et al. Breast conservation surgery, with and without radiotherapy, in women with lymph node-negative breast cancer: a randomized clinical trial in a population with access to public mammography screening. Eur J Cancer 2003; 39: 1690-1697.

17. Kurtz JM, Amalric R, Brandone $\mathrm{H}$ et al. Local recurrence after breast conserving surgery and radiotherapy. Frequency, time course, and prognosis. Cancer 1989; 63: 1912-1917.
18. Freedman GM, Anderson PR, Hanlon AL et al. Pattern of local recurrence after conservative surgery and whole-breast irradiation. Int J Radiat Oncol Biol Phys 2005; 61: 1328-1336.

19. Krauss DJ, Kestin LL, Mitchell C et al. Changes in temporal patterns of local failure after breast-conserving therapy and their prognostic implications. Int J Radiat Oncol Biol Phys 2004; 60: 731-740.

20. Veronesi U, Marubini E, Del Vecchio M et al. Local recurrences and distant metastases after conservative breast cancer treatments: partly independent events. J Natl Cancer Inst 1995; 87: 19-27.

21. Fisher B, Anderson S, Bryant J et al. Twenty-year follow-up of a randomized trial comparing total mastectomy, lumpectomy, and lumpectomy plus irradiation for the treatment of invasive breast cancer. N Engl J Med 2002; 347: 1233-1241.

22. Forrest AP, Stewart HJ, Everington D et al. Randomized controlled trial of conservation therapy for breast cancer: 6-year analysis of the Scottish trial. Scottish Cancer Trials Breast Group. Lancet 1996; 348: 708-713.

23. Fisher B, Bryant J, Dignam JJ et al. Tamoxifen, radiation therapy, or both for prevention of ipsilateral breast tumor recurrence after lumpectomy in women with invasive breast cancers of one centimeter or less. J Clin Oncol 2002; 20: 4141-4149.

24. Winzer KJ, Sauer R, Sauerbrei W et al. Radiation therapy after breast conserving surgery; first results of a randomized clinical trial in patients with low risk of recurrence. Eur J Cancer 2004; 40: 998-1005.

25. Potter R, Gnant M, Kwasny W et al. Lumpectomy plus tamoxifen or anastrozole with or without whole breast irradiation in women with favorable early breast cancer. Int J Radiat Oncol Biol Phys 2007; 68: 334-340.

26. Resch A, Fellner C, Mock U et al. Locally recurrent breast cancer: pulse dose rate brachytherapy for repeat irradiation following lumpectomy a second chance to preserve the breast. Radiology 2002; 225: 713-718.

27. Sauer G, Strnad V, Kurzeder C et al. Partial Breast Irradiation after Breast-Conserving Surgery. Strahlenther Onkol 2005; 181: $1-8$.

28. Weed DW, Edmundson GK, Vicini FA et al. Accelerated partial breast irradiation: A dosimetric comparison of three different techniques. Brachytherapy 2005; 4: 121-129.

29. Offersen BV, Overgaard M, Kroman N et al. Accelerated partial breast irradiation as part of breast conserving therapy of early breast carcinoma: A systematic review. Radiother Oncol 2009; 90: 1-13.

30. Njeh CF, Saunders MW, Langton CM. Accelerated Partial Breast Irradiation (APBI): A review of available techniques. Radiation Oncol 2010, 5: 90; doi:10.1186/1748-717X-5-90.

31. Strauss JB, Dickler A. Accelerated partial breast irradiation utilizing balloon brachytherapy techniques. Review of partial breast brachytherapy. Radiother Oncol 2009; 91: 157-165.

32. Polgár C, Van Limbergen E, Pötter R et al. Patient selection for accelerated partial-breast irradiation (APBI) after breastconserving surgery: Recommendations of the Groupe Européen de Curiethérapie - European Society for Therapeutic Radiology and Oncology (GEC-ESTRO) breast cancer working group based on clinical evidence. Radiother Oncol 2010; 94: 264-273.

33. Keller B, Sankreacha R, Rakovitch E et al. A permanent breast seed implant as partial breast radiation therapy for early-stage patients: a comparison of palladium-103 and iodine- 125 isotopes based on radiation safety considerations. Int J Radiat Oncol Biol Phys 2005; 62: 358-365.

34. Pignol J-P, Rakovitch E, Keller B et al. Tolerance and acceptance results of a palladium-103 permanent breast seed implant phase I/II study. Int J Radiat Oncol Biol Phys 2009; 73: 1482-1488. 
35. Scanderbeg DJ, Yashar C, Rice R et al. Clinical implementation of a new HDR brachytherapy device for partial breast irradiation. Radiother Oncol 2009; 90: 36-42.

36. Weed DW, Edmundson GK, Vicini FA et al. Accelerated partial breast irradiation: A dosimetric comparison of three different techniques. Brachytherapy 2005; 4: 121-129.

37. Dickler A, Kirk MC, Chu J et al. The MammoSiteTM breast brachytherapy applicator: A review of technique and outcomes. Brachytherapy 2005; 4: 130-136.

38. Perera F, Chisela F, Engel M et al. Method of localization and implantation of the lumpectomy cavity for high dose rate brachytherapy after conservative surgery for T1 and T2 breast cancer. Int J Radiat Oncol Biol Phys 1995; 31: 4959-4966.

39. Kirk M, Hsi WC, Dickler A et al. Surface Optimization Technique for MAMMOSITE Breast Brachytherapy Applicator. Int J Radiat Oncol Biol Phys 2005; 62: 366-372.

40. Kini V. Balloon breast brachytherapy - review of current data. Brachytherapy 2005; 4: 181-182.

41. Forszpaniak J. Balloon brachytherapy: how I do it. Nowotwory 2004; 1: 11-14.

42. Keisch M, Arthur DW. Current perspective on the MammoSite Radiation Therapy System - A balloon breast brachytherapy applicator. Brachytherapy 2005; 4: 177-180.

43. White J. MammoSite and accelerated partial breast irradiation: Rethinking one-size-fits-all breast irradiation after lumpectomy. Brachytherapy 2005; 4: 183-185.

44. Wazer DE, Kaufman S, Cuttino L et al. Accelerated Partial Breast Irradiation: An Analysis Of Variables Associated With Late Toxicity And Long-Term Cosmetic Outcome After HighDose-Rate Interstitial Brachytherapy. Int J Radiat Oncol Biol Phys 2006; 64: 489-495.

45. De la Rochefordière A, Abner AL, Silver B et al. Are cosmetic results following conservative surgery and radiation therapy for early breast cancer dependent on technique? Int J Radiat Oncol Biol Phys 1992; 23: 925-917.

46. Rivard MJ, Davis SD, DeWerd LA et al. Calculated and measured brachytherapy dosimetry parameters in water for the Xoft Axxent X-Ray Source: an electronic brachytherapy source. Med Phys 2006; 33: 4020-4032.

47. Dickler A, Patel RR, Wazer D. Breast brachytherapy devices. Expert Rev Med Devices 2009; 6: 325-333.

48. Smitt MC, Kirby R. Dose-volume characteristics of a $50-\mathrm{kV}$ electronic brachytherapy source for intracavitary accelerated partial breast irradiation. Brachytherapy 2007; 6: 207-211.

49. Chen PY, Vicini FA, Benitez P et al. Longterm cosmetic results and toxicity after accelerated partial-breast irradiation: a method of radiation delivery by interstitial brachytherapy for the treatment of early-stage breast carcinoma. Cancer 2006; 106: 991-999.

50. Sarin R. Partial-breast treatment for early breast cancer: emergence of a new paradigm. Nat Clin Pract Oncol 2005; 2: 40-47.

51. Strnad V, Hildebrandt G, Potter R et al. Accelerated Partial Breast Irradiation: 5-Year Results of the German-Austrian Multicenter Phase II Trial Using Interstitial Multicatheter Brachytherapy Alone After Breast-Conserving Surgery. Int J Radiat Oncol Biol Phys 2011; 80: 17-24.

52. Antonucci JV, Wallace M, Goldstein NS et al. Differences in patterns of failure in patients treated with accelerated partial breast irradiation versus whole-breast irradiation: a matchedpair analysis with 10-year follow-up. Int J Radiat Oncol Biol Phys 2009; 74: 447-452.

53. Johansson B, Karlsson L, Liljegren G et al. Pulsed dose rate brachytherapy as the sole adjuvant radiotherapy after breastconserving surgery of T1-T2 breast cancer: first long time results from a clinical study. Radiother Oncol 2009; 90: 30-35.
54. Arthur DW, Winter K, Kuske RR et al. A Phase II trial of brachytherapy alone after lumpectomy for select breast cancer: tumor control and survival outcomes of RTOG 95-17. Int J Radiat Oncol Biol Phys 2008; 72: 467-473.

55. Polgar C, Fodor J, Major T et al. Breast-conserving treatment with partial or whole breast irradiation for low-risk invasive breast carcinoma 5-year results of a randomized trial. Int J Radiat Oncol Biol Phys 2007; 69: 694-702.

56. King TA, Bolton JS, Kuske RR et al. Long-term results of widefield brachytherapy as the sole method of radiation therapy after segmental mastectomy for T(is,1,2) breast cancer. Am J Surg 2000; 180: 299-304.

57. Ott OJ, Hildebrandt G, Potter R et al. Accelerated partial breast irradiation with multi-catheter brachytherapy: Local control, side effects and cosmetic outcome for 274 patients. Results of the German-Austrian multi-centre trial. Radiother Oncol 2007; 82: 281-286.

58. Polgar C, Major T, Fodor J et al. Accelerated partial-breast irradiation using high-dose-rate interstitial brachytherapy: 12-year update of a prospective clinical study. Radiother Oncol 2010; 94: 274-279.

59. Keisch M, Vicini F, Kuske RR et al. Initial clinical experience with the MammoSite breast brachytherapy applicator in women with early-stage breast cancer treated with breast-conserving therapy. Int J Radiat Oncol Biol Phys 2003; 55: 289-293.

60. Chao KK, Vicini FA, Wallace M et al. Analysis of treatment efficacy, cosmesis, and toxicity using the MammoSite breast brachytherapy catheter to deliver accelerated partial-breast irradiation: the William Beaumont hospital experience. Int J Radiat Oncol Biol Phys 2007; 69: 32-40.

61. Zannis V, Beitsch P, Vicini F et al. Descriptions and outcomes of insertion techniques of a breast brachytherapy balloon catheter in 1403 patients enrolled in the American Society of Breast Surgeons MammoSite breast brachytherapy registry trial. Am J Surg 2005; 190: 530-538.

62. Richards GM, Berson AM, Rescigno J et al. Acute toxicity of high-dose-rate intracavitary brachytherapy with the MammoSite applicator in patients with early-stage breast cancer. Ann Surg Oncol 2004; 11: 739-746.

63. Vicini F, Beitsch P, Quiet C et al. Three-year analysis of treatment efficacy, cosmesis, and toxicity by the American society of breast surgeons MammoSite breast brachytherapy registry trial in patients treated with accelerated partial breast irradiation (APBI). Cancer 2008; 112: 758-766.

64. Vicini FA, Beitsch PD, Quiet CA et al. First analysis of patient demographics, technical reproducibility, cosmesis and early toxicity: results of the American society of surgeons MammoSite breast brachytherapy registry trial. Cancer 2005; 104 : 1138-1148.

65. Sadeghi A, Prestidge B, Lee J et al. Evaluation of the surface radiation dose and dose gradient in early stage breast cancer using high-dose-rate brachytherapy MammoSite applicator. Brachytherapy 2006; 5: 230-234.

66. DiFronzo LA, Tsai PI, Hwang JM et al. Breast conserving surgery and accelerated partial breast irradiation using the MammoSite system. Arch Surg 2005; 140: 787-794.

67. Tsai PI, Ryan M, Meek K et al. Accelerated partial breast irradiation using the MammoSite device: early technical experience and short-term clinical follow-up. Am Surg 2006; 72: 929-934.

68. Chen S, Dickler A, Kirk M et al. Patterns of failure after MammoSite brachytherapy partial breast irradiation: a detailed analysis. Int J Radiat Oncol Biol Phys 2007; 69: 25-31.

69. Dickler A, Kirk MC, Choo J et al. Cosmetic outcome and incidence of infection with the MammoSite breast brachytherapy applicator. Breast J 2005; 11: 306-310. 
70. Harper JL, Jenrette JM, Vanek KN et al. Acute complications of MammoSite brachytherapy: a single institution's initial clinical experience. Int J Radiat Oncol Biol Phys 2005; 61: 169-174.

71. Shah NM, Tenenholz T, Arthur D et al. MammoSite and interstitial brachytherapy for accelerated partial breast irradiation: factors that affect toxicity and cosmesis. Cancer 2004; 101: 727-734.

72. Evans SB, Kaufman SA, Price LL et al. Persistent seroma after intraoperative placement of MammoSite for accelerated partial breast irradiation: incidence, pathologic anatomy, and contributing actors. Int J Radiat Oncol Biol Phys 2006; 65: 333-339.

73. Niehoff $\mathrm{P}$, Polgar C, Ostertag H et al. Clinical experience with the MammoSite radiation therapy system for brachytherapy of breast cancer: results from an international phase II trial. Radiother Oncol 2006; 79: 316-320.

74. Niehoff P, Ballardini B, Polgar C et al. Early European experience with the MammoSite radiation therapy system for partial breast brachytherapy following breast conservation operation in low risk breast cancer. Breast 2006; 15: 319-325.

75. Benitez PR, Keisch ME, Vicini F et al. Five-year results: the initial clinical trial of MammoSite balloon brachytherapy for partial breast irradiation in early stage breast cancer. $\mathrm{Am}$ J Surg 2007; 194: 456-462.

76. Dragun AE, Harper JL, Jenrette JM et al. Predictors of cosmetic outcome following MammoSite breast brachytherapy: a single-institution experience of 100 patients with two years of follow-up. Int J Radiat Oncol Biol Phys 2007; 68: 354-358.

77. Jeruss JS, Vicini FA, Beitsch PD et al. Initial outcomes for patients treated on the American Society of Breast Surgeons MammoSite clinical trial for ductal carcinoma-in-situ of the breast. Ann Surg Oncol 2006; 13: 967-976.

78. Belkacémi Y, Chauvet MP, Giard S et al. Partial breast irradiation as soletherapy for low risk breast carcinoma: early toxicity, cosmesis and quality of life results of a MammoSite brachytherapy phase II study. Radiother Oncol 2009; 90: 23-29.

79. Voth M, Budway R, Leleher A et al. Local recurrence of breast cancer after MammoSite brachytherapy. Am Surg 2006; 72: 798-800.

80. Baglan KL, Martinez AA, Frazier RC et al. The use of highdose-rate brachytherapy alone after lumpectomy in patients with early-stage breast cancer treated with breast-conserving therapy. Int J Radiat Oncol Biol Phys 2001; 50: 1003-1011.

81. Vicini FA, Kestin L, Chen P et al. Limited-field radiation therapy in the management of early-stage breast cancer. J Natl Cancer Inst 2003; 95: 205-211.

82. Benitez PR, Chen PY, Vicini FA et al. Surgical considerations in the treatment of early stage breast cancer with accelerated partial breast irradiation (APBI) in breast conserving therapy via interstitial brachytherapy. Am J Surg 2004; 188: 355-364.

83. King TA, Bolton JS, Kuske RR et al. Long-term results of widefield brachytherapy as the sole method of radiation therapy after segmental mastectomy for $\mathrm{T}($ is, 1,2$)$ breast cancer. Am J Surg 2000; 180: 299-304.

84. Kuske RR, Winter K, Arthur DW et al. Phase II trial of brachytherapy alone after lumpectomy for select Brest cancer: toxicity analysis of RTOG 95-17. Int J Radiat Oncol Biol Phys 2006; 65: 45-51.

85. Perera F, Yu E, Engel J, Holliday R et al. Patterns of Breast recurrence in a pilot study of brachytherapy confined to the lumpectomy site for early breast cancer with six years' minimum follow-up. Int J Radiat Oncol Biol Phys 2003; 57: 1239-1246.

86. Arthur DW, Koo D, Zwicker RD et al. Partial Brest brachytherapy after lumpectomy: low-dose-rate and high-dose-rate experience. Int J Radiat Oncol Biol Phys 2003; 56: 681-689.
87. Wazer DE, Lowther D, Boyle $\mathrm{T}$ et al. Clinically evident fat necrosis in women treated with high-dose-rate brachytherapy alone for early-stage breast cancer. Int J Radiat Oncol Biol Phys 2001; 50: 107-111.

88. Wazer DE, Berle L, Graham R et al. Preliminary results of a phase I/II study of HDR brachytherapy alone for T1/T2 breast cancer. Int J Radiat Oncol Biol Phys 2002; 53: 889-897.

89. Lawenda BD, Taghian AG, Kachnic LA et al. Dose-volume analysis of radiotherapy for T1N0 invasive breast cancer treated by local excision and partial breast irradiation by low-doserate interstitial implant. Int J Radiat Oncol Biol Phys 2003; 56: 671-680.

90. Kaufman SA, DiPetrillo TA, Price LL et al. Long-term outcome and toxicity in a phase I/II trial using high-dose-rate multicatheter interstitial brachytherapy for T1/T2 breast cancer. Brachytherapy 2007; 6: 286-292.

91. Krishnan L, Jewell WR, Tawfik OW et al. Breast conservation therapy with tumor bed irradiation alone in a selected group of patients with stage I breast cancer. Breast J 2001; 7: 91-96.

92. Fentiman IS, Poole C, Tong D et al. Inadequacy of iridium implant as sole radiation treatment for operable Brest cancer. Eur J Cancer 1996; 32: 608-611.

93. Fentiman IS, Poole C, Tong D et al. Iridium implant treatment without external radiotherapy for operable breast cancer: a pilot study. Eur J Cancer 1991; 27: 447-450.

94. Fentiman IS, Deshmane V, Tong D et al. Caesium137 implant as sole radiation therapy for operable breast cancer: a phase II trial. Radiother Oncol 2004; 71: 281-285.

95. Polgar C, Sulyok Z, Fodor J et al. Sole brachytherapy of the tumor bed after conservative surgery for $\mathrm{T} 1$ breast cancer: five-year results of a phase I-II study and initial findings of a randomized phase III trial. I Surg Oncol 2002; 80: 121-128.

96. Polgar C, Major T, Fodor J et al. High-dose-rate brachytherapy alone versus whole breast radiotherapy with or without tumor bed boost after breast-conserving surgery: seven-year results of a comparative study. Int J Radiat Oncol Biol Phys 2004; 60: 1173-1181.

97. Lovey K, Fodor J, Major T et al. Fat necrosis after partialbreast irradiation with brachytherapy or electron irradiation versus standard whole-breast radiotherapy-4-year results of a randomized trial. Int J Radiat Oncol Biol Phys 2007; 69: 724-731.

98. Ott OJ, Lotter M, Sauer R et al. Accelerated partial-breast irradiation with interstitial implants: the clinical relevance of the calculation of skin doses. Strahlenther Onkol 2007; 183: 426-431.

99. Ott OJ, Pötter R, Hammer J et al. Accelerated partial breast irradiation with iridium-192 multicatheter PDR/HDR brachytherapy: preliminary results of the German-Austrian multicenter trial. Strahlenther Onkol 2004; 180: 642-649.

100. Ott OJ, Schulz-Wendtland R, Uter W et al. Fat necrosis after conserving surgery and interstitial brachytherapy and/or external-beam irradiation in women with breast cancer. Strahlenther Onkol 2005; 181: 638-644.

101. Harris JR, Levine M, Svensson G et al. Analysis of the cosmetic results following primary radiation therapy for stages I and II carcinoma of the breast. Int J Radiat Oncol Biol Phys 1979; 5: 257-261.

102. Cox JD, Stetz J, Pajak TF. Toxicity criteria of the Radiation Therapy Oncology Group (RTOG) and the European Organization for Research and Treatment of Cancer (EORTC). Int J Radiat Oncol Biol Phys 1995; 31: 1341-1346.

103. LENT SOMA tables. Radiother Oncol 1995; 35: 17-60. 